\title{
Penetrating keratoplasty in patients with traumatic corneal scarring
}

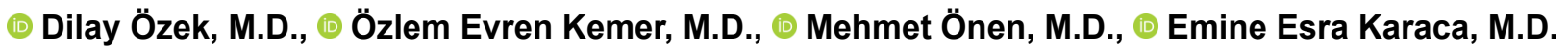

Department of Ophthalmology, Ankara Numune Training and Research Hospital, Ankara-Turkey

\begin{abstract}
BACKGROUND: To evaluate the results of penetrating keratoplasty (PK) due to trauma-related corneal scarring.

METHODS: We evaluated 24 eyes of 24 patients who underwent PK due to trauma-related scarring of the cornea between May 2010 and June 2016. The postoperative visual acuity, graft transparency, and complications were evaluated.

RESULTS: The patients were divided into two groups. In group I, I 4 eyes of patients with traumatic corneal scars and retinal detachment underwent PK, pars plana vitrectomy, and intravitreal silicone administration with the help of temporary keratoprosthesis. Group

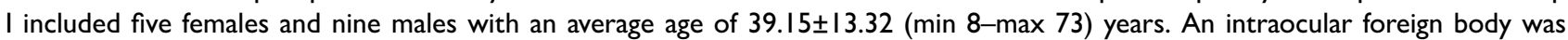
removed from five of the eyes. The mean visual acuity was $3.01 \pm 0.013(3.10-1.00) \log M A R$ after the surgery, I.36 $\pm 0.23(3.10-0.80)$ at the postoperative first month, and $1.18 \pm 0.03(3.10-0.70)$ at the end of the first year after the removal of keratoplasty sutures. During the follow-up of patients, two eyes (14.2\%) lost light sensation, eight eyes (57.1\%) developed postoperative glaucoma, nine eyes $(64.2 \%)$ had graft rejection, and one patient $(7.1 \%)$ developed keratitis. In one eye (7.1\%), the cornea was scraped using ethylenediaminetetraacetic acid due to silicone-related band keratopathy. In group 2, ten eyes with trauma-related corneal scars underwent PK. This group included two females and eight males with an average age of $29.23 \pm 12.03$ (II-63) years. The mean visual acuity was $2.98 \pm 0.68$ (3.10-1.00) logMAR before the surgery, $0.58 \pm 0.22(1.80-0.30)$ at the postoperative first month, and $0.50 \pm 0.17(1.80-0.10)$ at the end of the first year. One eye (10\%) with iridodialysis developed glaucoma. Rejection was not seen in any of the patients. A statistically significant difference was observed in both groups with regard to visual acuity before operation, at I and 12 months after operation, and at 12 months for graft transparency rates $(p=0.015, p=0.021, p=0.001$, respectively).
\end{abstract}

CONCLUSION: In cases of eye injuries due to trauma, the eyes subjected to combined vitrectomy and PK had poor visual prognosis and high graft rejection rate compared to those subjected to PK as the only treatment.

Keywords: Penetrating keratoplasty; temporary keratoprosthesis; traumatic corneal scar.

\section{INTRODUCTION}

Trauma to the eyes is one of the most common causes of vision loss. It is frequently seen among the young, active working individuals aged 20-35 years. ${ }^{[1]}$ The prognostic factors for good visual acuity in open-eye injuries include the initial visual acuity, globe rupture, endophthalmitis, accompanying afferent pupillary defect, type of trauma, localization of the wound site, and retinal detachment. ${ }^{[2,3]}$ Other factors might also be pars plana vitrectomy (PPV), comorbid aphakia, and severe iris defect. ${ }^{[4]}$
Corneal repair with penetrating keratoplasty (PK) may be performed immediately after perforation or electively at a later date following the primary repair. ${ }^{[5]}$ A direct $P K$ treatment of the perforation has a high risk of complications, such as synechia, glaucoma, uveitis, and graft reject. ${ }^{[6]}$ PPV in the first week is recommended for the development of proliferative vitreoretinopathy in the cases of ocular trauma accompanied by retinal detachment. ${ }^{[7]}$ Thus, in our study, PK and retinal surgery were performed within an average of I week.

Cite this article as: Özek D, Evren Kemer Ö, Önen M, Karaca EE. Penetrating keratoplasty in patients with traumatic corneal scarring. Ulus Travma Acil Cerrahi Derg 2019;25:172-176.

Address for correspondence: Dilay Özek, M.D.

Ankara Numune Eğitim ve Araştırma Hastanesi, Göz Kliniği, Ankara, Turkey.

Tel: +90 312 - 5084000 E-mail: dilaytop@gmail.com

Ulus Travma Acil Cerrahi Derg 2019;25(2):172-176 DOI: 10.5505/tjtes.2018.18949 Submitted: 05.12.2017 Accepted: 19.09.2018 Online: 14.03.2019

Copyright 2019 Turkish Association of Trauma and Emergency Surgery 
In this study, patients treated with only PK for a trauma-related corneal penetrating scar in an open globe injury and those who underwent retina surgery together with PK were evaluated. All the patients were investigated in terms of visual acuity, graft transparency, and postoperative complications.

\section{MATERIALS AND METHODS}

The study was conducted in accordance with the ethical principles of the Helsinki Declaration after the approval from the ethics committee of a training and research hospital.

This retrospective study included 24 eyes of 24 patients who underwent PK for a trauma related corneal scar between May 2012 and June 2016. All patients underwent PK at an average of $12.03 \pm 1.13$ (13-47) weeks after the primary repair of corneal penetration. Ocular Trauma Classification was used to classify ocular trauma. ${ }^{[2]}$

We used the ocular trauma score for all patients, ${ }^{[2]}$ which was calculated as the raw points based on the initial best corrected visual acuity (no light perception $=60$ raw points, hand motion perception $=70$ raw points, $1 / 200$ to $19 / 200=80 \mathrm{raw}$ points, $20 / 200$ to $20 / 50=90$ raw points, and $\geq 20 / 40=100$ raw points) and other injury-related factors, including globe rupture = minus 23 raw points; endophthalmitis = minus 17 raw points; perforating injury $=$ minus 14 raw points; retinal detachment = minus II raw points; and afferent papillary defect $=$ minus 10 raw points. The total score was measured as $I .3 \pm 0.21$ in group $I$ and $2.34 \pm I .24$ in group 2 .

The patients were divided into two groups. In group I $(n=\mid 4$ eyes), the patients had retinal detachment with a corneal scar and hence combined PK, 20-gauge PPV, and intravitreal silicone injection were applied with temporary keratoprosthesis (TKP). Endodiathermy and endolaser were applied where necessary. Group 2 ( $n=10$ eyes) had only traumatic corneal scarring and thus PK was applied in those patients' eyes.

Grafts larger than $0.25 \mathrm{~mm}$ were used during PK. The donor cornea was sutured in an interrupted manner using 10/0 nylon sutures. In cases where PK was applied with TKP, the cornea was removed with trepanation and then TKP was inserted into the sclera using $6 / 0$ vicryl sutures through six holes on the keratoprosthesis. After application of 20-gauge PPV, the silicone was given, and the full-thickness donor cornea was sutured in an interrupted manner using 10/0 monofilament nylon sutures.

Visual acuity was assessed according to the Snellen chart. The intraocular pressure was measured using applanation tonometry. B-scan ultrasonography was performed in the eyes where the posterior pole could not be assessed for various reasons.

Graft transparency was defined as central graft transparency that did not decrease visual acuity.
Patients with previous systemic diseases, such as diabetes or hypertension, and eye diseases, such as retinal problems, amblyopia, or glaucoma, were excluded from the study.

All data were analyzed using the Statistical Package for Social Sciences (SPSSTM Inc., Chicago, IL, USA) 15.0 program for Windows. Continuous variables were expressed as mean \pm standard deviation. The data of the visual acuity and graft transparency rates of the two groups were assessed using the Wilcoxon test.

\section{RESULTS}

Group I included five females and nine males with an average age of $39.15 \pm 13.32(\min 8-\max 73)$ years. The mean follow-up period was $22.1 \mathrm{I} \pm 15.25$ (13-47) months. Wound locations were zone $I$ in 6 eyes, zone 2 in 6 eyes, and zone 3 in 2 eyes. An intraocular foreign body was extracted from five eyes. An Ahmed valve was applied to one eye with glaucoma and all-angle synechia. All the foreign bodies were removed via the sclerotomy for PPV using a three-leg foreign body forceps. The sclerotomy entry was expanded during foreign body removal in three eyes. In the eyes of patient in group I, pars plana lensectomy was performed during vitrectomy as the cataract lens and/or lens had dropped into the vitreous. In our study, all eyes in group I were given silicone tamponade; six eyes (42.8\%) had silicone retained for persistent hypotony, and two eyes (14.2\%) were given silicone again for retinal re-attachment.

Group 2 included two females and eight males with an average age of $29.23 \pm 12.03(1 \mid-63)$ years. The mean follow-up period was $18.11 \pm 10.32(13-31)$ months. The wound location was zone $I$ in 8 eyes and zone 2 in 2 eyes. In two eyes during the keratoplasty, the cataract lenses were removed during the surgery and replaced with an intraocular foldable lens. In one eye, the lens had developed cataract due to the use of steroids after PK. The lens was removed using the corneal tunneling phacoemulsification method and was replaced with an intraocular foldable lens. Postoperative complications are shown in Table I.

Table I. Postoperative complications

\begin{tabular}{lccccc}
\hline & \multicolumn{2}{c}{ Group I } & & \multicolumn{2}{c}{ Group 2 } \\
\cline { 3 - 4 } & $\mathbf{n}$ & $\%$ & & $\mathbf{n}$ & $\%$ \\
\hline Loss of light perception and & & & & \\
evisceration & 2 & 14.2 & & - & - \\
Graft rejection & 9 & 64.2 & & - & - \\
Post-keratitis leukoma & I & 7.1 & & - & - \\
Band keratopathy & I & 7.1 & & - & - \\
Glaucoma & 8 & 57.2 & & I & 10 \\
Re-keratoplasty & 6 & 42.8 & & - & - \\
\hline
\end{tabular}


Table 2. Visual acuity and graft transparency

\begin{tabular}{lccc}
\hline $\mathbf{n = 2 4}$ & Group I $(\mathbf{n}=\mathbf{l 4})$ & Group 2 $(\mathbf{n}=\mathbf{l 0})$ & $\mathbf{p}$ \\
\hline Before PK visual acuity (LogMAR) & $3.0 I \pm 0.013$ & $2.98 \pm 0.68$ & 0.056 \\
Visual acuity, first month (LogMAR) & $(3.10-1.00)$ & $(3.10-1.00)$ & \\
& $1.36 \pm 0.23$ & $0.58 \pm 0.22$ & $0.015^{*}$ \\
Visual Acuity, twelfth month (LogMAR) & $(3.10-0.80)$ & $(1.80-0.30)$ & \\
& $1.18 \pm 0.03$ & $0.50 \pm 0.17$ & $0.02 I^{*}$ \\
Graft transparency & $(3.10-0.70)$ & $(1.80-0.10)$ & \\
\hline PK: Penetrating keratoplasty. & $n=4$ & $n=10$ & $0.00 I^{*}$ \\
\hline
\end{tabular}

Postoperative glaucoma was controlled by medical treatment in eight eyes in group I and in one eye accompanied by iridodialysis in group 2.

Table 2 presents the compared data regarding the visual acuities according to the Snellen chart of the patients in both groups at the first and twelfth months postoperatively and the patients with preserved graft transparency.

At the preoperative period, the mean visual acuity was $3.01 \pm 0.013 \log M A R$ in group $I$ and $2.98 \pm 0.68$ in group 2 . At the postoperative first month, the visual acuities were $1.36 \pm 0.23$ and $0.58 \pm 0.22 \log$ MAR in groups $I$ and 2 , respectively. One year after removal of the all keratoplasty sutures, the last visual acuities were $1.18 \pm 0.03$ and $0.50 \pm 0.17 \log M A R$, in groups $\mathrm{I}$ and 2 , respectively. Statistically significant differences were determined between the two groups with respect to visual acuity before operation, at I and 12 months after operation, and at 12 months for graft transparency rates $(p=0.015, p=0.021, p=0.001$, respectively).

\section{DISCUSSION}

Ocular trauma involving the anterior segment reduces the visual acuity due to corneal scarring and high astigmatism. The visual acuity in such cases can be improved with hard contact lenses, but keratoplasty is an appropriate method when the usage of lens not possible. ${ }^{[8]}$

In case of serious injuries, ocular trauma affects not only the anterior segment but also the posterior segment. In ocular trauma, the cornea has been reported to be penetrated in $50 \%$ of cases. ${ }^{[9]}$

In severe ocular trauma, both anterior segment and the posterior segment are involved. The probability of retinal and choroidal damage is increased in zone 3 and larger wound length open globe injury. Such cases require retinal surgery in addition to keratoplasty. Retinal surgery alone may be performed if the opacity due to the corneal penetrating scar in the anterior segment is small and does not block vision dur- ing vitrectomy. However, when corneal opacity is extensive and corneal edema and vascularity are present, it prevents vision for retinal re-attachment, thorough cleaning of the vitreous base, and removal of the intraocular foreign body during vitrectomy. In these cases, PK and PPV may need to be combined. The first TKP was applied in 1981 by Landers et al. $^{[10]}$ The modified third generation wide-field TKP is made from polymethyl methacrylate and is available in different diameters of $6.2 \mathrm{~mm}, 7.2 \mathrm{~mm}$, or $8.2 \mathrm{~mm}$. Suturing provides a stable state, while the convex anterior surface allows detailed imaging of the entire retina including the peripheral retina. ${ }^{[1,12]}$ Despite retinal re-attachment rates of $43 \%-92 \%$, graft transparency of $15-75 \%$ has been reported in previous studies owing to the size of the initial trauma in retinal surgery with TKP. ${ }^{[7,13-16]}$ Postoperative insufficient visual acuity has been most commonly associated with graft failure, PVR, and secondary glaucoma, and the final visual acuity has been reported to be low. ${ }^{[16]}$ In the current study, 12 of 14 eyes $(85.7 \%)$ with anterior and posterior segment trauma showed a re-attached retina; $9(64.2 \%)$ eyes had graft rejection and the visual acuity was $0.015 \pm 0.023$.

Silicone oil can be retained in the trauma-affected eyes as persistent hypotony is often seen. It may lead to graft failure due to insufficient aqueous flow and silicone oil touching the graft endothelium. ${ }^{[17]}$ Chen et al. ${ }^{[18]}$ observed 74 eyes subjected to a PPV + TKP + PK combined procedure; 46 eyes $(62.2 \%)$ had persistent hypotony, and ten eyes (13.5\%) were enucleated due to atrophia bulbi. In the present study, 6 eyes (42.8\%) were detected with persistent hypotony and two eyes (14.2\%) lost light sensation after surgery due to atrophia bulbi for group $I$.

In a previous study, complications, such as postoperative glaucoma, have been reported in patients who underwent PK after trauma. ${ }^{[19]}$ In the current study, postoperative glaucoma was seen in eight eyes in group $I$ and in one eye in group 2. The glaucoma was controlled by medical treatment.

Retinal necrosis or massive proliferative vitreoretinopathy with closed funnel and hemorrhage are noted in severe retinal trauma. ${ }^{[16]}$ Silicone tamponade can be left in the eye for a 
long period to prevent PVR formation and retinal re-detachment, but it can cause corneal graft decompensation. ${ }^{[20]}$

Silicone keratopathy is one of the most common complications after silicone oil is applied during retinal surgery, and this develops at the rates of $11 \%-100 \% .^{[21-23]}$ Silicone keratopathy develops through the decompensatory effect of silicone on the corneal endothelium. In the current study, silicone keratopathy developed in three of the 14 eyes (21.4\%) and band keratopathy developed in one eye $(7.14 \%)$ treated with silicone.

The rate of endophthalmitis is between $0.9 \%-17 \%$ in open globe injuries. ${ }^{[24-26]}$ In our study, no endophthalmitis was reported, but one patient (7.I\%) developed keratitis in group I, and the cornea healed with a scar after the treatment.

There are two limitations of PK performed by retinal surgeons. First, no matter how successful the keratoplasty, the visual acuity is limited due to retinal damage. Secondly, silicone oil frequently used in retina surgeries causes graft failure in the postoperative period. A follow-up of keratoplasty cases with retinal surgery is very important. Patients should be evaluated in detail regarding the complications that may develop after the operation. The visual prognosis is low, and graft rejection and failure rates are high. Therefore, caution should be exercised when deciding upon the surgery, and the patient should be informed in detail.

Our study included eyes that had severe ocular trauma and underwent retinal surgery with TKP. The evaluation of complications that may occur in the postoperative period in such serious trauma increases the value of the current study.

Financial support: No competing financial interests exist.

\section{Conflict of interest: None declared.}

\section{REFERENCES}

1. Ries PW. Acute Conditions- Incidence and Associated Disability. National Health Survey. DHEW Publication No (PHS) 79-1560. Available at: https://www.cdc.gov/nchs/data/series/sr_10/sr10_132.pdf. Accessed Feb 6, 2019.

2. Kuhn F, Morris R, Witherspoon CD, Heimann K, Jeffers JB, Treister G. A standardized classification of ocular trauma. Ophthalmology 1996;103:240-3. [CrossRef]

3. Brinton GS, Aaberg TM, Reeser FH, Topping TM, Abrams GW. Surgical results in ocular trauma involving the posterior segment. Am J Ophthalmol 1982;93:271-8. [CrossRef]

4. Gursoy H, Bilgec MD, Sahin A, Colak E. A Possible Regression Equation for Predicting Visual Outcomes afterSurgical Repair of Open Globe Injuries. J Ophthalmol 2017;2017:1320457. [CrossRef]

5. Nobe JR, Moura BT, Robin JB, Smith RE. Results of penetrating keratoplasty for the treatment of corneal perforations. Arch Ophthalmol 1990;108:939-41. [CrossRef]

6. Dohlman CH, Boruchoff SA, Sullivan GL. A technique for the repair of perforated corneal ulcers. Arch Ophthalmol 1967;77:519-25. [CrossRef]
7. Dong X, Wang W, Xie L, Chiu AM. Long-term outcome of combined penetrating keratoplasty and vitreoretinal surgery using temporary keratoprosthesis. Eye (Lond) 2006;20:59-63. [CrossRef]

8. Landers MB 3rd, Foulks GN, Landers DM, Hickingbotham D, Hamilton RC. Temporary keratoprosthesis for use during pars plana vitrectomy. Am J Ophthalmol 1981;91:615-9. [CrossRef]

9. Colyer MH, Weber ED, Weichel ED, Dick JS, Bower KS, Ward TP, et al. Delayed intraocular foreign body removal without endophthalmitis during Operations Iraqi Freedom and Enduring Freedom. Ophthalmology 2007;114:1439-47. [CrossRef]

10. Eckardt C. A new temporary keratoprosthesis for pars plana vitrectomy. Retina 1987;7:34-7. [CrossRef]

11. Narendran V, Kothari AR, Charles S, Saravanan VR, Kreissig I. Principles and Practice of Vitreoretinal Surgery. New Delhi: Jaypee Brothers Medical Publishers; 2014.

12. Sharkey TG, Brown SI. Transplantation of lacerated corneas. Am J Ophthalmol 1981;91:721-5. [CrossRef]

13. Meredith TA, Gordon PA. Pars plana vitrectomy for severe penetrating injury with posterior segment involvement. Am J Ophthalmol 1987;103:549-54. [CrossRef]

14. Gelender H, Vaiser A, Snyder WB, Fuller DG, Hutton WL. Temporary keratoprosthesis for combined penetrating keratoplasty, pars plana vitrectomy, and repair of retinal detachment. Ophthalmology 1988;95:897-901.

15. Nowomiejska K, Haszcz D, Forlini C, Forlini M, Moneta-Wielgos J, Maciejewski R, et al. Wide-Field Landers Temporary Keratoprosthesis in Severe Ocular Trauma: Functional and Anatomical Results after One Year. J Ophthalmol 2015;2015:163675. [CrossRef]

16. Roters S, Szurman P, Hermes S, Thumann G, Bartz-Schmidt KU, Kirchhof B. Outcome of combined penetrating keratoplasty with vitreoretinal surgery for management of severe ocular injuries. Retina 2003;23:48-56.

17. Noorily SW, Foulks GN, McCuen BW. Results of penetrating keratoplasty associated with silicone oil retinal tamponade. Ophthalmology 1991;98:1186-9. [CrossRef]

18. Chen HJ, Wang CG, Dou HL, Feng XF, Feng K, Hu YT, et al. Anatomical outcome of vitreoretinal surgery using temporary keratoprosthesis and replacement of the trephined corneal button for severe open globe injuries: one-year result. J Ophthalmol 2014;2014:794039. [CrossRef]

19. Robinson LP. Keratoplasty following anterior segment trauma. Aust J Ophthalmol 1981;9:59-62. [CrossRef]

20. Mieler WF, Mittra RA. The role and timing of pars plana vitrectomy in penetrating ocular trauma. Arch Ophthalmol 1997;115:1191-2.

21. Federman JL, Schubert HD. Complications associated with the use of silicone oil in 150 eyes after retina-vitreous surgery. Ophthalmology 1988;95:870-6. [CrossRef]

22. Leaver PK, Grey RH, Garner A. Silicone oil injection in the treatment of massive preretinal retraction. II. Late complications in 93 eyes. $\mathrm{Br} \mathrm{J}$ Ophthalmol 1979;63:361-7. [CrossRef]

23. Haut J, Ullern M, Chermet M, Van Effenterre G. Complications of intraocular injections of silicone combined with vitrectomy. Ophthalmologica 1980;180:29-35. [CrossRef]

24. Ahmed Y, Schimel AM, Pathengay A, Colyer MH, Flynn HW Jr. Endophthalmitis following open-globe injuries. Eye (Lond) 2012;26:212-7.

25. Andreoli CM, Andreoli MT, Kloek CE, Ahuero AE, Vavvas D, Durand ML. Low rate of endophthalmitis in a large series of open globe injuries. Am J Ophthalmol 2009;147:601-8.e2. [CrossRef]

26. Soheilian M1, Rafati N, Mohebbi MR, Yazdani S, Habibabadi HF, Feghhi M, et al; Traumatic Endophthalmitis Trial Research Group. Prophylaxis of acute posttraumatic bacterial endophthalmitis: a multicenter, randomized clinical trial of intraocular antibiotic injection, report 2. Arch Ophthalmol 2007;125:460-5. [CrossRef] 


\section{ORİIINAL ÇALIŞMA - ÖZET}

\section{Travmatik korneal skarlı hastalarda penetran keratoplasti}

\section{Dr. Dilay Özek, Dr. Özlem Evren Kemer, Dr. Mehmet Önen, Dr. Emine Esra Karaca}

Ankara Numune Eğitim ve Araştırma Hastanesi, Göz Kliniği, Ankara

AMAÇ: Travma ilişkili korneal perforasyon skarı nedeniyle penetran keratoplasti (PK) uygulamalarının sonuçlarını değerlendirmek.

GEREÇ VE YÖNTEM: Çalışmamıza Mayıs 2010-Haziran 2016 tarihleri arasında travmatik korneal skar nedeniyle penetran keratoplasti uyguladığımız 24 hastanın 24 gözü alındı. Ameliyat sonrası hastalar görme keskinliği, greft saydamlığı ve komplikasyonlar açısından değerlendirildi. Hastalar iki gruba ayrıldı. Grup I'de travma ile ilişkili retina dekolmanı ve korneal perforasyon skarı olan I4 göz mevcut olup, bu hastalara PK, pars plana vitrektomi (PPV) ve intravitreal silikon verilmesi geçici keratoprotez (TKP) eşliğinde uygulandı. Grup 2 'de 10 gözde sadece travma ilişkili korneal perforasyon skarı olup PK uygulandı.

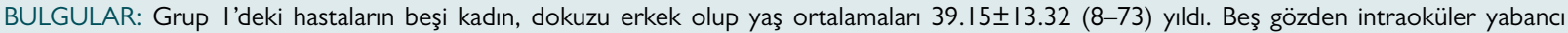
cisim çıkarıldı. Ortalama görme keskinliği LogMAR’a göre ameliyat öncesi $3.01 \pm 0.013$ (3.I0-I.00) iken ameliyat sonrası birinci ayda I.36 \pm 0.23

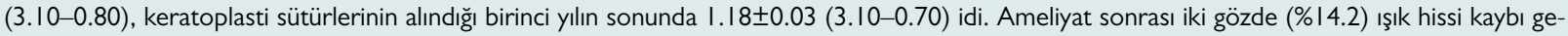
lişti ve evisserasyon yapıldı. Sekiz gözde (\%57.I) tıbbi tedavi ile kontrol altına alınabilen glokom, dokuz gözde (\%64.2) greft rejeksiyonu, bir gözde (\%7.I) keratit sonrası lökom, bir gözde (\%7.ı) silikona bağlı bant keratopati gelişti. Bant keratopati gelişen gözde EDTA ile kazıma yapıldı. Grup 2'deki hastaların ikisi kadın, sekizi erkek olup yaş ortalamaları 29.23 12.03 ( I I-63) yıldı. Ortalama görme keskinliği LogMAR'a göre ameliyat ön-

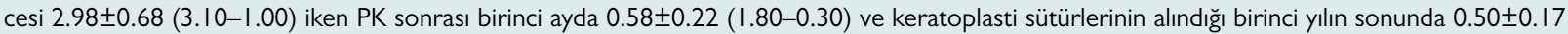
( $1.80-0.10)$ idi. İridodiyalizi olan bir gözde (\% I0) tıbbi tedavi ile kontrol altına alınabilen glokom gelişti. Hiçbir hastada korneal rejeksiyon görülmedi. Her iki grup arasında PK sonrası birinci ay ve 12. ay sonunda görme keskinlikleri ve greft saydamlığı açısından sırasıyla fark istatistiksel olarak anlamlıydı $(p=0.015, p=0.021, p=0.001)$.

TARTIŞMA: Göz travmalarında, ön ve arka segmenti ilgilendiren ve retina cerrahisi ile birlikte PK yapılan gözlerde sadece ön segmenti ilgilendiren ve PK yapılan gözlere göre görme prognozu ve greft saydamlık oranları düşüktür.

Anahtar sözcükler: Geçici keratoprotez; korneal skar; penetran keratoplasti.

Ulus Travma Acil Cerrahi Derg 2019;25(2): I72-I76 doi: 10.5505/tjtes.20।8.18949 